\title{
IMPLEMENTASI SURAT EDARAN MAHKAMAH AGUNG NOMOR 3 TAHUN 2015 PADA PENGADILAN AGAMA SAWAHLUNTO
}

\section{Muhammad Farhan ${ }^{1}$, Eficandra ${ }^{2}$, Roni Efendi ${ }^{3}$}

\author{
1 Institut Agama Islam Negeri, Batusangkar \\ e-mail: farhansyaddad9@gmail.com \\ 2 Institut Agama Islam Negeri, Batusangkar \\ e-mail: eficandra@iainbatusangkar.ac.id \\ ${ }^{3}$ Institut Agama Islam Negeri, Batusangkar \\ e-mail: roniefendi@iainbatusangkar.ac.id
}

\begin{tabular}{|l|l|l|}
\hline Submit: 23-06-2020 & $\begin{array}{l}\text { Direvisi: 09-09, 13-10, } \\
\text { O6-10,- 2020 }\end{array}$ & Dipublish: 18-12-2020 \\
\hline
\end{tabular}

Abstract: The urgency of this research is to examine the implementation of the Supreme of the Court Circular Number 32015 on the addition of liveliboods for children from 10\% to 20\% per year. Since the determination Supreme of the Court Circular in the Family Court of Sawablunto, in 2018 were 7 decisions have been made, 3 to applicated and 4 doesn't. The inequality when considering the jury leads to three fundamental questions: What is the position of Supreme of the Court Circular in the concept of the positivist legal philosophy? What are the Judges considerations to implementing and not implementing Supreme of the Court Circular? Howabout the Islamic Law perspective to Supreme of the Court Circular in terms of adding child livelihood? To answer the object of research, the implementation Supreme of the Court Circular Family Court Sawablunto is extensively examined as sociological/ empirical legal research. The results of this research philosophically Supreme of the Court Circular is a harmonization between Islamic law and positive law, on the condition that Supreme of the Court Circular offers the jury a guarantee of legal certainty when deciding on the addition of a child. Consideration of the jury in the implementation of Supreme of the Court Circular to ensure that children's livelihoods are met in terms of economic needs that further improve and maintain descendant relationships for those who do not implement Supreme of the Court Circular due to the limited ability of their fathers. Supreme of the Court Circular's perspective on Islamic law regarding the addition of a child at 10\% to 20\% per year is relevant to the problem of the Maslahah Mursalah, which is to maintain hereditary relationships.

Kata kunci: Surat Edaran Mahkamah Agung, Nafkah Anak, Pengadilan Agama Sawahlunto.

\section{PENDAHULUAN}

$\mathcal{A}$ llah SWT telah menciptakan perempuan supaya mereka saling kenalmengenal dan menetapkan norma yang relevan dengan fitrah manusia agar marwah dan kehormatannya dapat terjaga. Allah SWT tidak menghendaki manusia memiliki perilaku yang sama dengan makhluk lainnya (binatang) yang senang melampiaskan nafsunya dengan bebas. Oleh karena itu, Allah SWT menjadikan hubungan antara laki-laki dan perempuan dalam ikatan yang suci yaitu perkawinan. Perkawinan merupakan pola hidup yang ditetapkan oleh 
Allah SWT untuk melanjutkan keturanan. (Sabiq, 2011)

Perkawinan dalam Pasal 1 Undangundang Nomor 16 Tahun 2019 Perubahan atas Undang-Undang Nomor 1 Tahun 1974 (Selanjutnya ditulis UU Perkawinan) merupakan ikatan lahir batin antara seorang pria dan wanita sebagai suami istri dengan tujuan membentuk keluarga (rumah tangga) yang bahagia dan kekal berdasarkan Ketuhanan Yang Maha Esa. Maka perkawinan adalah sunnatullah sebagai suatu cara yang dipilih oleh Allah SWT untuk manusia dalam melanjutkan keturunan serta melestarikan kehidupan. (Syahrani, 2009) Sangat rasional ketika Islam menetapkan ketentuan untuk mengatur fungsi keluarga, sehingga dengan perkawinan suami dan istri dapat memperoleh kedamaian, kecintaan, keamanan, dan iktan kekerabatan. Unsur-unsur ini sangat urgen dalam mencapai tujuan perkawinan yang paling besar yaitu ibadah kepada Allah SWT. (Rahman, 1996)

Pembinaan perkawinan berasaskan pada satu cita ketentraman hidup sekaligus sebagai pembentukan masyarakat yang harmonis. (Rozali, 2017) Tujuan dan esensi perkawinan adalah mewujudkan rasa sakinah mawaddah wa rahmah serta melanjutkan keturunan, sebagaimana Firman Allah SWT dalam Surah Ar-Rum ayat 21 yang berbunyi;

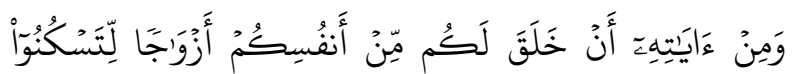

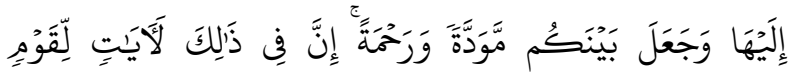
"يَتَفَكَُورونَ

"dan di antara tanda-tanda kekuasaan-Nya ialah Dia menciptakan untukmu isteri-isteri dari jenismu sendiri, supaya kamu cenderung dan merasa tenteram kepadanya, dan dijadikan-Nya di antaramu rasa kasih dan sayang. Sesungguhnya pada yang demikian itu benar-benar terdapat tanda-tanda bagi kaum yang berfikir".

Tujuan perkawinan menurut Pasal 1 UU "Perkawinan adalah membentuk keluaraga (rumah tangga) yang bahagia dan kekal berdasarkan Ketuhanan Yang Maha Esa". Kemudian di dalam Intruksi Presiden Nomor 1 tahun 1991 Tentang Kompilasi Hukum Islam (selanjutnya ditulis KHI) Pasal 3 perkawinan bertujuan "untuk mewujudkan rumah tangga sakinah mawaddah wa rahmah". Tujuan perkawinan ini niscaya akan menghasilkan dan melingkupi banyak pandangan tentang fungsi keluarga untuk memenuhi kebutuhan emosional dan seksual yang sah serta suatu bentuk ibadah yaitu pengabdian kepada Allah SWT dan mengikuti Sunnah Rasulullah SAW, sehingga dapat terwujud keluarga yang harmonis. (Rahman, 1996)

Menciptakan hubungan yang harmonis bukanlah perkara yang muda, namun demikian Allah SWT memberi petunjuk untuk mencegah terjadinya hubungan yang tidak diinginkan. Salah satu cara yaitu memerintahkan seseorang yang berpengaruh, seandainya mereka khawatir terjadinya pertengkaran (syiqaq) antara suami dan istri, untuk menghindarkan dari perceraian. (Sabiq, 2009). Perceraian sering disebut juga dengan talaq, akar kata talaq adalah alithlaq, artinya melepaskan atau menghilangkan. Dalam syariat Islam, talaq artinya melepaskan ikatan pernikahan atau mengakhirinya. Dimaksudkan dengan mengakhiri hubungan suami istri ialah mengangkat hubungan suami istri sehingga keduanya istri tidak lagi halal bagi suaminya. (Syahrani, 2009)

Perceraian berdampak di berbagai aspek yang tidak saja bagi pelakunya. (Safala, 2015) tetapi juga mempengaruhi perilaku anak seperti prilaku anti sosial. (Sarianti, 2019) Di samping penyimpangan perilaku anak, perceraian 
menimbulkan kewajiban nafkah kepada istri selama masa iddah dan kepada anak hingga sudah dewasa. Nafkah ialah sesuatu yang diberikan suami kepada istri dan anaknya untuk memenuhi keperluan pokok meliputi sandang, pangan dan papan serta biaya pendidikan bagi anaknya. (Z. Ali, 2006)

Firman Allah SWT dalam surah Annisa ayat 34 yang berbunyi:

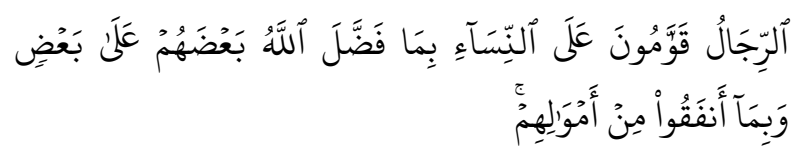

"kaum laki-laki itu adalah pemimpin bagi kaum wanita, oleh karena Allah telah melebihkan sebahagian mereka (laki-laki) atas sebahagian yang lain (wanita), dan karena mereka (laki-laki) telah menafkahkan sebagian dari harta mereka".

Di sisi lain Pasal 149 KHI juga sebagai pedoman bagi hakim dalam memutus dan menentukan nilai nafkah anak, pedoman dimaksud juga berkaitan dengan ukuran kepatutan atau kelayakan dan terutama ukuran keadilan bagi anak serta ayahnya. Penentuan nilai nafkah anak wajib memperhatikan berbagai aspek. (Asnawi, 2016) Di antara peraturan tersebut Pasal $156 \mathrm{KHI}$ huruf (d) menegaskan "semua biaya hadhanah dan nafkah anak menjadi tanggung jawab ayah menurut kemampuannya, sekurang-kurangnya sampai anak tersebut dan dapat mengurus diri sendiri sampai umur 21 tahun". (Instruksi Presiden Nomor 1 Tahun 1991 Tentang Kompilasi Hukum Islam., n.d.)

Selanjutnya dalam Pasal 1 angka 1 Undang-Undang Nomor 4 tahun 1979 tentang Kesejahteraan Anak menjelaskan bahwa "kesejahteraan anak adalah suatu tata kehidupan dan penghidupan anak yang dapat menjamin pertumbuhan dan perkembangannya dengan wajar, baik secara rohani, jasmani, maupun sosial" dan pada Pasal 2 disebutkan mengenai hak-hak anak.

1. "Anak berhak atas kesejahteraan, perawatan, asuhan dan bimbingan berdasarkan kasih sayang baik dalam keluarganya maupun di dalam asuhan khusus untuk tumbuh dan berkembang dengan wajar.

2. Anak berhak atas pelayanan untuk mengembangkan kemampuan dan kehidupan sosialnya, sesuai dengan kebudayaan dan kepribadian bangsa, untuk menjadi warga Negara yang baik dan berguna.

3. Anak berhak atas pemeliharaan dan perlindungan, baik sesama dalam kandungan maupun sesudah dilahirkan.

4. Anak berhak atas perlindungan terhadap lingkungan hidup yang dapat membahayakan atau menhambat pertumbuhan dan perkembangannya dengan wajar".

Regulasi di atas relevan dengan hakikat keberadaan manusia sebagai makhluk Allah SWT yang diperintahkan untuk melaksanakan dan menghentikan segala yang dilarang. Bila diteliti semua perintah dan larangan mempunyai tujuan tertentu dan tidak ada yang sia-sia serta untuk mewujudkan maqasid syariah. Hukum syarak tersebut meliputi seluruh peraturan dan tata cara kehidupan dalam Islam yang diperintahkan oleh Allah SWT yang termaktub di dalam al-Qur'an dan Sunnah. (Daud, 2004) Tujuan Allah SWT mensyari'atkan hukumnya adalah untuk mewujudkan kemaslahatan bagi manusia sekaligus untuk menghindari kerusakan hidup. Kemaslahatan itu melalui analisis maqasid syariah tidak hanya dilihat dalam arti teknis belaka, akan tetapi dalam upaya pengembangan 
hukum dilihat sebagai sesuatu yang mengandung nilai filosofis. (Jaya, 1996)

Dalam rangka mengimplementasikan maqasid syariah, Mahkamah Agung RI pada tanggal 9 sampai dengan 11 Desember 2015 telah menyelenggarakan rapat pleno kamar untuk membahas permasalahan hukum (questions of law) dan salah satu objek rapat tersebut adalah berkaitan dengan penambahan nafkah anak sebagaimana diatur dalam Sema di atas. Dalam penelitian awal, Armen Ghani Hakim Pengadilan Agama Sawahlunto mengemukakan bahwa salah satu pertimbangan munculnya Sema Nomor 3 tahun 2015 adalah terus meningkatnya harga kebutuhan primer sandang, pangan dan papan. Kemudian berdasarkan penelitian awal yang Peneliti lakukan di Pengadilan Agama Sawahlunto, pada tanggal 9 November 2019, bahwa terdapat 7 Putusan Pengadilan Agama Sawahlunto di tahun 2018 terkait penerepan Sema Nomor 3 Tahun 2015 tentang Penambahan Nafkah Anak 10\% sampai dengan 20\% pertahun dari jumlah yang ditetapkan, dan di luar biaya pendidikan dan kesehatan. Dalam pengamatan Peneliti, di Pengadilan Agama Sawahlunto terjadi perbedaan atas pertimbangan majelis dalam mengimplemetasikan Sema Nomor 3 tahun 2015. Di mana 3 (tiga) putusan menerapkan dan 4 (empat) yang tidak menerapkannya sebagaimana dalam tabel berikut:

Tabel 1.

\begin{tabular}{|c|l|l|}
\hline NO & \multicolumn{1}{|c|}{ Nomor perkara } & \multicolumn{1}{|c|}{ Keterangan } \\
\hline 1 & Nomor 190/Pdt.G/2018/PA SWL & Menambahkan $10 \%$ pertahun \\
\hline 2 & Nomor 167/Pdt.G/2018/PA SWL & Menambahkan $10 \%$ pertahun \\
\hline 3 & Nomor 82/Pdt.G/2018/PA SWL & Menambahkan 10\% pertahun \\
\hline 4 & Nomor 3/Pdt.G/2018/PA SWL & Tidak Menambahkan \\
\hline 5 & Nomor 139/Pdt.G/2018/PA SWL & Tidak Menambahkan \\
\hline 6 & Nomor 151/Pdt.G/2018/PA SWL & Tidak Menambahkan \\
\hline 7 & Nomor 205/Pdt.G/2018/PA SWL & Tidak Menambahkan \\
\hline
\end{tabular}

(sumber data: Pengadilan Agama Sawahlunto)

Dari delapan putusan Pengadilan Agama Sawahlunto tentang nafkah anak, dapat dianalisis terjadinya disparitas pertimbangan majelis hakim dalam mengimplementasikan Sema Nomor 3 Tahun 2015 terkait penambahan nafkah anak. Adapun urgensi penelitian ini untuk mengkaji beberapa objek penelitian yaitu: bagaimana kedudukan Sema Nomor 3 Tahun 2015 perspektif filsafat postivis? Bagaimana pertimbangan majelis hakim dalam mengimplementasikan dan tidak mengimplementasikan Sema Nomor 3 Tahun 2015? Serta, bagaimana perspektif hukum Islam terhadap Sema Nomor 3 Tahun 2015?

\section{METODE PENELITIAN}

Jenis penelitian yang digunakan dalam penelitian ini adalah penelitian empiris/field research yaitu mengidentifikasi dan mengkonsepsikan hukum sebagai institusi sosial yang riil dan fungsional dalam sistem kehidupan yang mempola. (Soekanto \& Sri Mamudji, n.d.) yakni mengidentifikasi penerapan Sema Nomor 3 Tahun 2015 di Pengadilan Agama Sawah Lunto. Adapun sumber 
data yang Peneliti gunakan dalam Penelitian ini adalah sebagai berikut:

1. Sumber Data Primer yang Peneliti peroleh secara langsung dari sumber aslinya berupa Putusan Pengadilan Agama Sawahlunto tentang nafkah anak, Ketua Pengadilan Agama, Hakim dan Panitera atau Sekretaris Pengadilan Agama Sawahlunto.

2. Sumber Data Sekunder adalah bukubuku, referensi lain yang relevan dengan objek kajian. Dalam penelitian ini Peneliti juga menggunakan bahan hukum primer yang meliputi UUD, UU Perkawinan, Kompilasi Hukum Islam serta Surat Edaran Mahkamah Agung Nomor 3 Tahun 2015.

\section{NAFKAH DAN MAQASID SYARIAH}

\section{Nafkah}

Secara terminologi kata nafkah berasal dari kata Al-Nafaqah (biaya hidup) merupakan hak istri dan anakanak dalam hal makanan, pakaian dan kediaman, serta beberapa kebutuhan pokok lainnya dan pengobatan, bahkan sekalipun istri adalah seorang wanita yang kaya. Nafkah dalam bentuk ini wajib hukumnya berdasarkan AlQur'an, Al-Sunnah dan Ijma' Ulama, bila kedua pasangan itu telah samasama dewasa, maka merupakan kewajiban sang suami, bukannya istri seperti yang terjadi di beberapa Negara barat saat ini, memberikan makanan, pakaian dan kediaman bagi istri dan anak-anaknya sesuai dengan tingkat kedudukan sosial pasangan tersebut dan selaras dengan adat kebiasan masyarakat di tempat tinggal mereka. (Rahman, 1996)
Nafkah merupakan kewajiban suami terhadap istrinya dalam bentuk materi, karena kata nafaqah itu berkonotasi materi. Sedangkan kewajiban dalam bentuk non materi, seperti memuaskan hajad seksual istri tidak termasuk dalam artian nafaqah, meskipun dilakukan suami terhadap istrinya. (Elimartati, 2016) Berikut di antara dasar hukum kewajiban memberi nafkah dalam al-Qur'an yakni surat Al-Baqarah ayat 233, surat AthThalaq ayat 6 dan lain-lain. Selain dalam Al-Qur'an pengaturan nafkah juga dapat ditemu di dalam hadist, seperti Dari Bukhari dan Muslim meriwayatkan dari Aisyah ra. Bahwasanya Hindu binti Utbah berkata, wahai Rasulullah, Abu Sufyan adalah laki-laki yang kikir. Dia tidak memberikan nafkah kepadaku dan juga anakku selain apa yang aku ambil darinya tanpa sepengetahuannya, beliau kemudian bersabda:

$$
\text { خزي ما يكفيك وولدك بالمعروف }
$$

"Ambillah yang mencukupimu dan anakmu dengan sepatutnya."

Hakim bin Muawiyah al-Qusyairy ra. Berkata, aku bertanya kepada Rasulullah SAW, wahai Rasulullah, apa hak istri salah seorang di antara kami yang harus dipenuhinya? Beliau menjawab,

$$
\text { تضعمها اد طعمت وتكسوها اذا اكتسيت ولا }
$$

"Hendaknya kamu memberinya makan jika kamu makan dan memberinya pakaian jika kamu mengenakan pakaian, 
dan jangan memukul wajah jangan menjelek-jelekkan, serta jangan berseteru kecuali di dalam rumah."

Adapun landasan atas wajibnya memberi nafkah sesuai dengan ijma' ulama adalah, Ibnu Qudamah berkata, para ulama sepakat bahwa memberi nafkah kepada istri merupakan kewajiban yang harus dipenuhi suami jika suami sudah berusia baliq kecuali terhadap istri yang membangkang. Hal ini disampaikan oleh ibnu munzir dan yang lain. Dia berkata, ini mengandung satu bentuk pelajaran, yaitu bahwasanya perempuan tertahan pada suami yang membuatnya tidak dapat beraktifitas dengan leluasa dan mencari penghasilan, maka suami harus memenuhi kebutuhannya dengan memberikan nafkah.

"Dari Muhammad bin Mungkadir, bahwasanya laki-laki datang kepada Rasulullah SAW. Dan berkata: "Wahai Rasulullah bahwasanya aku mempunyai harta dan anak dan sungguh bapakku ingin mengambil hartaku maka memberinya kepada anak-anaknya". Kemudian Rasulullah menjawab: "Engkau dan hartamu milik ayahmu".

Hadits di atas menjelaskan, bahwa engkau dan hartamu milik ayahmu walaupun engkau mempunyai anak tetapi hartamu milik ayahmu. Diriwayatkan oleh Ibnu Majah dari Jabir bin Abdillah Thabrani meriwayatkan dalam al-Jamiul Kabir Barzan dari Samurah dan Ibnu Mas'ud. Baihaqi mengetahui salah seorang yang menyatakan sanad hadits ini bersambung sampai pada Jabir.kata Hafiz Ibnu Hajar. "Sanadnya orang kepercayaan". Namun Bazar menyebutkan hadits ini hanya dikenal dari Hisyam dari AlManawi mengenai hal ini. Jadi Bukhari mengisyaratkan kedhaifan hadits ini. Adapun sebab-sebab penurunan hadits tersebut dijelaskan bahwa di dalam sunan Ibnu Majah dari Jabir diceritakan bahwa seorang laki-laki menyampaikan pada Nabi SAW, katanya wahai Rasulullah "sesungguhnya saya memiliki harta dan anak sedangkan ayahku bermaksud hendak menghabiskan hartaku itu, maka Rasul menjawab "Engkau dan hartamu milik ayahmu"

Ibnu Rusyd dalam kitabnya Bidayah Al-Mujtahid, mengemukakan pendapat Imam Malik dan Abu Hanifah ini bahwa besarnya nafkah tidak ditentukan oleh Syara' akan tetapi berdasarkan pada keadaan masingmasing suami dan istri. dan hal ini akan berbeda berdasarkan perbedaan tempat, waktu dan keadaan.(Rusyd, 1990).

\section{Maqasid Syariah}

Maqasid al-Syariah terdiri dari dua kata yaitu مقا صد dan الثر يعة. Berarti membawa sesuatu, juga berarti permintaan, maksud dan tujuan. Syariah menurut bahasa berarti jalan menuju sumber air yang juga dapat diartikan sebagai jalan menuju sumber keadilan utama. Maqasid merupakan jamak dari kata Maqshad dari kata qasada-yaqshudu-qasdan-maqshadan

berarti ketugahan pada satu jalan. Maqashid adalah sesuatu yang dilakukan dengan penuh pertimbangan dan ditunjukan untuk mencapai sesuatu yang dapat mengantarkan seseorang kepada jalan yang lurus (kebenaran), kebenaran yang didapatkan itu mestilah diyakininya serta diamalkannya secara teguh. 
Selanjutnya dengan melakukan sesuatu itu diharapkan dapat menyelesaikan masalah yang dihadapinya dalam kondisi apapun. (Busyro, 2015)

Berkenaan dengan kemaslahatan yang harus diwujudkan itu apabila dilihat dari segi kepentingan dan kekuatannya, al-Syathibi dan ulamaulama lainnya membaginya kepada tiga tingkatan yang terdiri dari daruriyat, hijayat dan tahsiniyat. (Busyro, 2015) Tuntutan kebutuhan manusia itu bertingkat-tingkat secara berurutan yaitu:

1) Al-dharuriyah (kebutuhan primer)

Al-dhaririyah menurut ulama ushul fiqih adalah segala sesuatu yang harus ada untuk tegaknya kemaslahatan manusia, baik agamanya maupun dunianya. Apabila al-dharuriyah ini tidak ada dan tidak terpelihara dengan baik, maka rusaklah kehidupan manusia di dunia dan akhirat. Dengan kata lain al-dharuriyah adalah tujuan esensial dalam kehidupan manusia demi untuk menjaga kemaslahatan mereka.

2) Al-Hajiyah (kebutuhan sekunder) Al-hajiyyah adalah suatu kebutuhan yang juga mesti dipunyai oleh manusia, dan keberadaannya akan membuat hidup manusia akan lebih mudah dan terhindar dari kesulitan. Oleh karena itu orang yang tidak memperoleh atau mengedepankan kebutuhan al-hajiyah ini pada dasarnya tidak akan membuat kehidupannya hancur dan berantakan, tetapi akan mendapatkan kesulitan, baik dalam menjalankan aktifitas keduniawian maupun ukhrawinya. Misalnya diperbolehkan mengambil keringanan yang diberikan oleh Allah SWT seperti menqashar shalat bagi musafir, berbuka puasa bagi musafir dan orang sakit.

Amir Syarifuddin mengatakan bahwa defenisi di atas sesungguhnya al-hajiyah adalah sesuatu yang dapat menyampaikan seseorang untuk memelihara kebutuhan aldharuriyah, dengan demikian alhajiyah merupakan sesuatu yang harus dilakukan oleh seseorang terlebih dahulu untuk melaksanakan perintah-perintah Allah SWT dan untuk menghindarkan diri dari larangan-Nya.

3) Al-Tahsiniyah (kebutuhan tertier) Al-tahsiniyah merupakan kebutuhan manusia untuk menyempurnakan sesuatu yang dilakukan dan membuatnya lebih indah dan penuh kewibawaan. Apablia hal ini tidak didapatkan oleh manusia sebenarnya tidak akan merusak tatanan hidupnya, dan juga tidak akan menyulitkan. Tetapi keberadaannya akan menghasilkan kesempurnaan dan nilai keindahan serta akhlak yang tinggi. Dengan demikian kebutuhan pada tingkat ini tidak akan menghalangi terlaksananya pemeliharaan kebutuhan pelengkap misalnya memakai harum-haruman ketika pergi menghadiri shalat berjamaah, mandi sebelum jum'at, belajar diruangan yang bagus dan memakai media yang modern dan sebagianya

Tujuan tingkat tahsiniyah adalah sesuatu yang sebaiknya ada 
untuk memperindah kehidupan. Tanpa terpenuhi kebutuhan tersier, kehidupan tidak akan rusak dan tidak akan menimbulkan kesulitan. Adapun kelompok tahsiniyah adalah kebutuhan yang menunjang peningkatan martabat hidup seseorang dalam masyarakat dan dihadapan Allah SWT dalam kewajaran dan keputusan. (Shindiq, 2011)

\section{KEDUDUKAN SEMA NOMOR 3 TAHUN 2015 PERSPEKTIF ALIRAN POSITIVIS.}

Di Indonesia, istilah negara hukum secara konstitusional telah ditegaskan dalam landasan konstitusional yakni UUD 1945. Sehingga negara hukum merupakan negara yang berdiri di atas hukum dan menjamin keadilan kepada warga negaranya di mana keadilan tersebut merupakan syarat bagi tercapainya kebahagian hidup untuk warga negara. Istilah negara tersebut dimuat dalam Pasal 1 ayat (3) UUD 1945, sehingga seluruh sendi kehidupan dalam bermasyarakat, berbangsa dan bernegara harus berdasarkan pada norma-norma hukum. Artinya, hukum harus dijadikan sebagai jalan keluar dalam penyelesaian masalah-masalah yang berkenaan dengan perorangan maupun berkelompok. (Erwin, 2011). Pada hakikatnya menjadikan negara Indonesia sebagai negara hukum yang memiliki karakteristik mandiri yang berarti kemandirian tersebut terlihat dari penerapan konsep atau pola negara hukum yang dianutnya. Kemudian yang dimaksud dengan hukum, menurut aliran filsafat hukum positifis, hukum adalah "law is a command of the law giver" hukum adalah perintah dari penguasa yang dapat dilihat dalam ketentuan Undang-Undang. (A. Ali, 2002)
Karena posvitisme hukum berpandangan bahwa hukum seyogyanya nyata dalam kodifikasi karena dengan tertulisnya hukum, maka hukum dapat diverifikasi. Mazhab positivisme ini sangat mengutamakan hukum tertulis, sehingga mazhab ini berasumsi bahwa tidak ada norma di luar hukum positif.(Efendi, 2016). Dalam suatu negara hukum menurut Marwan Mas (Is \& Sobandi, 2019) mengharuskan adanya pengakuan secara normatif dan empirik terhadap prinsip supremasi hukum, yaitu bahwa semua masalah diselesaikan dengan hukum sebagai pedoman tertinggi. Pengakuan normatif mengenai supremasi hukum terwujud dalam pembentukan norma hukum secara hierarkis yang berpuncak pada supremasi konstitusi. Adapun secara empirik terwujud dalam prilaku pemerintahan dan masyarakat yang mendasarkan pada aturan hukum yang berlaku.

Maka Sema Nomor 3 tahun 2015 merupakan harmonisasi antara hukum Islam dan hukum positif yang sejalan dengan cita yang diajarkan oleh aliran positivistik. Harmonisasi dimaksud adalah mengadob hukum Islam kedalam peraturan perundang-undangan sebagai pengakuan normatif melalui pembentukan norma hukum sehingga terdapat legalitas untuk diimplementasikan dan terjaminnya kepastian hukum yang secara empirik menjadi dasar masyarakat khususnya Majelis Hakim dalam menetapkan putusan penambahan nafkah anak.

Pemberlakuan rumusan hasil rapat pleno kamar Mahkamah Agung tahun 2015 sebagai pedoman pelaksanaan tugas bagi Pengadilan dan penerapan sistem kamar di Mahkamah Agung RI salah satu 
bertujuan untuk menjaga kesatuan penerapan hukum dan konsistensin putusan. Rapat pleno kamar adalah salah satu istrumen untuk mewujudkan tujuan pedoman pelaksanaan bagi Hakim agar berjalan semestinya. Terdapat di Kamar Agama No 14 dari hasil rapat pleno kamar Mahkamah Agung menyatakan "amar mengenai pembebenan nafkah anak hendaknya diikuti dengan penambahan $10 \%$ sampai dengan $20 \%$ per tahun dari jumlah yang ditetapkan, di luar biaya pendidikan dan kesehatan" ketentuan tersebut menjadi acuan bagi hakim di Pengadilan Agama Sawahlunto untuk menaikan nafkah anak $10 \%$ sampai $20 \%$.

Dari hasil analisis, benar bahwa hadirnya Sema Nomor 3 Tahun 2015 merupakan rujukan bagi hakim yang memiliki jaminan kepastian hukum, namun keberadaan Sema tersebut baru bersifat fakultatif. Artinya Sema Nomor 3 Tahun 2015 bukan suatu keharusan bagi hakim untuk mempedomani dan menerapkan dalam setiap putusannya, karena kedudukan Sema di bawah Undang-Undang, tidak setara atau lebih tinggi dari Undang-Undang, maka sema hanya mengikat ke dalam lingkungan peradilan saja. Seyogyanya Sema Nomor 3 Tahun 2015 ditingkatkan statusnya setara dengan peraturan perundang-undangan mengingat betapa urgent materi muatan yang diatur di dalamnya, sehingga Sema Nomor 3 Tahun 2015 bukan lagi sebagai pilihan untuk diterapkan atau tidak diterapkan. Ketika kedudukan Sema Nomor 3 Tahun 2015 dinaikkan atau disetarakan dengan peraturan perundangundangan maka akan menggeser kedudukannya menjadi imperative yang wajib dipedomani oleh hakim dalam memutus perkara yang berkaitan dengan nafkah anak, sehingga relevan dengan ajaran mazhab postivis, karena hukum merupakan perintah dari penguasa yang berdaulat maka dengan sifat memaksanya akan memberikan jaminan kepastian nafkah anak pasca putusnya perkawinan kedua orang tua nya. Mengingat dari putusan Pengadilan Agama Sawahlunto yang ditelitipada 2018 terdapat 7 perkara, 3 perkara menerapkan Sema No 3 tahun 2015 dan 4 perkara tidak menerapkan Sema No 3 tahun 2015 tentang penambahan nafkah anak $10 \%$ sampai $20 \%$ pertahun. Hal ini membuktikan bahwa keberadaan Sema Nomor 3 Tahun 2015 masih dikesampingkan.

\section{PERTIMBANGAN MAJELIS HAKIM TENTANG IMPLEMENTASI SURAT EDARAN MAHKAMAH AGUNG NO 3 TAHUN 2015 TENTANG PENAMBAHAN NAFKAH ANAK DI PENGADILAN SAWAHLUNTO \\ AGAMA}

Dari penelitian yang Peneliti lakukan di Pengadilan Agama Sawahlunto terdapat 7 putusan sepanjang tahun 2018 yang berkaitan dengan Sema Nomor 3 tahun 2015 tantang penambahan nafkah anak $10 \%$ sampai $20 \%$ per tahun. Dari 7 putusan 3 di antaranya menerapkan Sema dan 4 diantaranya tidak. Berikut di bawah ini adalah 3 putusan Pengadilan Agama Sawahlunto yang di dalamnya Pertimbangan Majelis mengimplementasikan Sema Nomor 3 Tahun 2015.
a. Perkara Nomor 190/Pdt.G/2018/PA SWL.
Dalam perkara ini Pengadilan Agama Sawahlunto mengadili perkara 
tertentu pada tingkat pertama dalam perkara cerai talak saudaraYM. Kedua nya suami istri sah yang menikah pada tanggal 4 Maret 1999 di Kecamatan Lembar Segar, Kota Sawahlunto. Bahwa pemohon telah mengajukan permohonan Cerai Talak tanggal 3 September 2018, setelah menikah pemohon dengan termohon telah bergaul sebagaimana layaknya suami istri dan dikarunia 2 orang anak, yaitu:

1) Anak pertama, laki-laki, lahir tanggal 14 Januari 2000;

2) Anak kedua, perempuan, lahir tanggal 25 januari 2006;

Bahwa Penggugat Rekonvensi mengajukan tuntutan kepada Tergugat Rekonvensi untuk menyerahkan hak pengasuhan 2 (dua) orang anak dan tidak menetapkan berapa jumlah minimal tuntutan nafkah. Pertimbangan hukum oleh Majelis Hakim tentang berapa besarnya jumlah nafkah anak yang harus ditanggung oleh seorang ayah adalah ditentukan berdasarkan pada kemampuan seorang ayah. Tergugat Rekonvensi adalah seorang Pegawai Negeri Sipil dengan gaji/penghasilan kurang lebih Rp. 5.000.000,- (lima juta rupiah) setiap bulan dari penghasilan tersebut yang bersangkutan hanya mengeluarkan uang untuk kebutuhan pribadinya tanpa ada tanggungan lain. Sebagaimana diatur dalam ketentuan pasal 105 Huruf (c) jo pasal 149 Huruf (d) Kompilasi Hukum Islam di Indonesia, sebagaimana dikemukakan oleh Imam Taqiudin Abi Bakar Muhammad; "Biaya pemeliharan anak ditanggung oleh ayahnya".
Bahwa berdasarkan uraian-uraian dalam pertimbangan tersebut maka Majelis Hakim berpendapat sangat wajar dan memenuhi rasa keadilan apabila Tergugat Rekonvensi ditetapkan dan dihukum untuk memberikan nafkah 2 orang anak Penggugat Rekovensi dan Tergugat Rekonvensi sebesar Rp. 1.500.000,(satu juta lima ratus ribu rupiah) setiap bulannya dan ditambah 10\% setiap tahunnya sampai anak tersebut dewasa.

b. Perkara Nomor 167/Pdt.G/2018/PA SWL.

Kasus perkara cerai talak yang diajukan tanggal 06 Agustus 2018 dikarenakan termohon tidak menghargai pemohon mengatakan kata-kata kotor kepada pemohon seperti mengatakan kata-kata carutan dan termohon juga membuat hutang dengan banyak para pihak dan telah pisah rumah selama 3 tahun lamanya dan telah dikarunia 4 orang anak.

1) Anak pertama, perempuan, lahir tanggal 01 Agustus 1992

2) Anak kedua, laki-laki, lahir tanggal 22 Agustus 1999

3) Anak ketiga, laki-laki, lahir tanggal 18 Oktober 2003

4) Anak keempat, laki-laki, lahir tanggal 06 Agustus 2010

Berdasarkan pertimbangan Majelis Hakim bahwa terhadap tuntutan Penggugat Rekonvensi tentang nafkah untuk 4 orang anak Penggugat Rekonvensi dan Tergugat Rekonvensi, sebagai akibat hukum karena permohonan cerai yang diajukan oleh Pemohon/Tergugat Rekonvensi telah dikabulkan, maka terhadap gugatan balik/Rekonvensi 
tersebut, Majelis Hakim dalam pertimbangannya bahwa sesuai dengan Kitab I'anatut thalibin juz IV halaman 99 yang diambil sebagai pendapat Majelis Hakim "Anak yang masih punya bapak dan ibu, maka bapak yang wajib menafkahinya". Berdasarkan Pasal 45 ayat (1) Undang-Undang Perkawinan disebutkan bahwa kedua orang tua wajib memelihara dan mendidik anakanak mereka sebaik-baiknya, dan ayat (2) disebutkan bahwa kewajiban orang tua yang dimaksud dalam ayat (1) berlaku sampai anak itu kawin atau dapat berdiri sendiri. Untuk memberikan nafkah kepada 4 orang anak Penggugat Rekonvensi menuntut nafkah sebesar Rp. 1.000.000, (satu juta rupiah) sampai anak tersebut dewasa/mandiri, Tergugat Rekonvensi menyang-gupinya dan ditambah 10\% pertahun, maka Majelis akan mempertimbangkan nafkah yang layak untuk diberikan kepada dua orang anak Penggugat Rekonvensi dan Tergugat Rekonvensi yang tentunya disesuaikan dengan kemampuan Tergugat Rekonvensi.

c. Perkara Nomor 82/Pdt.G/2018/PA SWL.

Dalam perkara cerai talak yang diajukan 21 Maret 2018 dikarenakan pertengkaran dan perselisihan yang tidak dapat diselasaikan baik dari pihak keluarga maupun melalui Mediasi Hakim, yang telah menjalin hubungan selama 8 tahun dan telah dikarunia 2 orang anak:
1) Anak pertama, Laki-laki Lahir tanggal 21 April 2002
2) Anak kedua, Laki-laki lahir tanggal 27 Juni 2009

Berdasarkan Pertimbangan Majelis Hakim bahwa pokok sengketa yang tidak perlu dibuktikan adalah tentang nafkah anak. Kendati dalam petitum gugatan rekonvensi, Penggugat Rekonvensi tidak mencantumkan jumlah tuntutan untuk nafkah anak, namun dalam positanya terdeskripsikan keinginan Penggugat Rekonvensi untuk menuntut nafkah anak. Menimbang, bahwa dalam petitum jawaban Tergugat Rekonvensi menyatakan bahwa, Tergugat Rekonvensi bersedia memberikan nafkah untuk 2 orang anak sebanyak Rp. 3.000.000 (tiga juta rupiah) setiap bulannya sampai anak tersebut dewasa dan mandiri.

Dalam pertimbangan Majelis Hakim bahwa karena Tergugat Rekonvensi bersedia memberikan nafkah anak sebesar Rp. 3.000.000,- (tiga juta rupiah) setiap bulannya sampai anak tersebut dewasa dan mandiri serta tidak keberatan dan bantahan yang diajukan oleh Penggugat Rekonvensi, maka Majelis Hakim berpendapat bahwa untuk nafkah anak tidak perlu dibuktikan lebih lanjut, karena sudah ada kesediaan dari Tergugat Rekonvensi untuk memberikan nafkah anak sebesar Rp. 3.000.000,- (tiga juta rupiah) setiap bulannya sampai anak tersebut dewasa dan mandiri dan di tambah $10 \%$ per tahun sampai anak tersebut dewasa.

Berdasarkan wawancara dengan Ketua Pengadilan Agama Sawahlunto Bapak Doni Dermawan, S.H.I.,M.H.I pada tanggal 18 Mei 2020 tentang penambahan nafkah dijelaskan sangat bermanfaat bagi anak karena tercukupinya kebutuhan berupa sandang, 
pangan dan papan sesuai perkembangan ekonomi tiap tahunnya. Senada dengan penjelasaBapak Armen Ghani tanggal 18 Mei 2020 Hakim Pengadilan Agama Sawahlunto menjelaskan bahwa Sema Nomor 3 tahun 2015 memiliki kedudukan yang sangat penting secara materil karena akan berkaitan dengan kesejahteraan anak sebagai akibat perceraian orang tuanya, kesejahteraan tersebut ditunjukkan dengan adanya penambahan nafkah anak $10 \%$ sampai $20 \%$ per tahun untuk menyesuaikan dengan inflansi mata uang. Sedangkan manfaat selanjutnya dari Sema Nomor 3 tahun 2015 sebagai acuan dan dasar hukum bagi hakim di lingkungan peradilan Agama untuk menambahkan nafkah anak sebesar $10 \%$ sampai $20 \%$ per tahun.

Contoh penambahan nafkah anak $10 \%$ sampai $20 \%$ per tahun sampai anak tersebut dewasa dan berdiri sendiri dapat mengacu tabel berikut:

\begin{tabular}{|c|c|c|}
\hline No & $\begin{array}{c}\text { Jumlah Nafkah } \\
\text { Anak }\end{array}$ & Tahun \\
\hline 1. & $1.000 .000+10 \%$ & 2000 \\
\hline 2. & $1.100 .000+10 \%$ & 2001 \\
\hline 3. & $1.200 .000+10 \%$ & 2002 \\
\hline
\end{tabular}

Dari tabel di atas bahwa Sema Nomor 3 tahun 2015 sangat penting mengingat terus terjadinya peningkatan-peningkatan ekonomi tiap tahun, sehingga menambahkan nafkah anak $10 \%$ sampai $20 \%$ per tahun adalah hal yang sangat wajar dan realitis. Maka Majelis Hakim dalam menerapkan Sema Nomor 3 tahun 2015 beserta besaran nominalnya ditetapkan berdasarkan kemampuan ayah. Hal ini sesuai berdasarkan Pasal 156 Huruf (f)
Kompilasi Hukum Islam yang menyatakan bahwa: "Pengadilan dapat pula dengan melihat kemampuan ayahnya menentukan jumlah biaya untuk pemeliharaan dan pendidikan anak-anak yang tidak turut padanya". Hakim juga memutus berdasarkan pembuktian-pembuktian dimuka sidang. Menurut ketentuan Pasal 164 HIR/ Pasal 284 RBg ada lima macam alat bukti yaitu bukti surat, bukti saksi, persangkaan, pengakuan, sumpah. Mengenai hal tersebut yaitu pembebanan nafkah yang di jatuhkan pengadilan kepada ayahnya yaitu melakukan pembuktian-pembuktian selama persidangan. (Dermawan, 2020)

Sedangkan beberapa putusan di bawah ini berkaitan dengan pertimbangan Majelis Hakim yang tidak menerapkan SEMA No 3 tahun 2015 di Pengadilan Agama Sawahlunto. a. Perkara Nomor 139/Pdt.G/2018/PA SWL.

Kasus perkara cerai talak yang diajukan tanggal 03 Juli 2018 di Pengadilan Agama Sawahlunto, rumah tangga bapak Amar yang berjalan akur selama 7 tahun, kemudian di tahun 2013 rumah tangga bapak Amar tidak harmonis lagi, karena sering terjadi perselisihan dan pertengkaran yang tidak bisa didamaikan kembali, selama masa perkawinan telah dikarunia 3 orang anak diantaranya:

1) Anak pertama, laki-laki, lahir tahun 2000

2) Anak kedua, perempuan, lahir tahun 2003

3) Anak ketiga, lahir tanggal 19 Agustus 2009. 
Berdasarkan pertimbangan Majelis Hakim tentang nafkah anak yang dalam perkara ini dari gugatanPenggugat Rekonvensi tentang nafkah untuk 3 orang anak sebagai akibat hukum karena permohonan cerai yang diajukan oleh pemohon telah dikabulkan berdasarkan Kitab I'anatul thalibin Juz IV halaman 99 yang berbunyi "anak yang masih punya bapak dan ibu, maka bapaknya wajib menafkahi.Kemudian, salah satu akibat yang timbul dari perceraian antara suami dan istri yang telah menpunyai anak adalah persoalan nafkah anak, sampai anak tersebut dewasa atau mampu berdiri sendiriyang mengacu Pasal 45 ayat (1) Undang-Undang Perkawinan merupakan kewajiban kedua orang tuanya. Sehingga Majelis Hakim mengabulkan tuntutan Penggugat Rekonvensi terhadap Tergugat Rekopensi untuk memberikan nafkah kepada 3 orang anak sebesar Rp. 5.000.000,- (lima juta rupiah) sampai anak tersebut dewasa/mandiri, selanjutnya Tergugat Rekonvensi menyanggupi untuk memberikan nafkah kepada 3 orang anak sebesar Rp. 5.000.000,- (lima Juta rupiah) setiap bulan.

Maka majelis hakim akan mempertimbangkan nafkah yang layak untuk diberikan kepada 3 orang anak Penggugat Rekonvensi dan Tergugat Rekonvensi yang tentunya disesuaikan dengan kemampuan Tergugat Rekonvensi. Dalam putusan ini hakim tidak menambahkan nafkah anak 10\% sampai $20 \%$ per tahun, dikarenakan nafkah yang telah disanggupi Tergugat Rekonvensi jumlahnya cukup besar.

b. Perkara Nomor 205/Pdt.G/2018/PA SWL

Kasus perkara Cerai Talak yang diajukan tanggal 17 September 2018 di Pengadilan Agama Sawahlunto, rumah tangga saudara Dd yang akur selama kurang lebih 7 tahun, kemudian pada tahun 2017 terjadinya pertengkaran dan perselisihan yang disebabkan perselingkuhan oleh termohon dengan laki-laki lain sehingga tidak dapat didamaikan dan mereka telah dikarunia 2 orang anak.

1) Anak Pertama, laki-laki, kira-kira lahir tahun 2012

2) Anak Kedua, perempuan, kirakira lahir tahun 2014.

Berdasarkan pertimbangan Majelis Hakim Pengadilan Agama Sawahlunto bagi nafkah anak yang ditinggalkan atas perceraian kedua orangtuanya, yang terdapat dalam Pasal 45 ayat (1) UU Perkawinan serta Pasal 105 huruf (c) KHI bahwa dalam hal terjadinya perceraian anatara pasangan suami istri "biaya pemeliharaan anak ditanggung oleh ayah".

Dalam putusan tersebut di atas tuntutan Penggugat Rekonvensi kepada Tergugat Rekonvensi untuk memberikan nafkah kepada 2 orang anak sebesar Rp. 1.200.000,- (satu juta dua ratus ribu rupiah) sampai anak tersebut dewasa/mandiri, Tergugat Rekonvensi hanya menyanggupinya untuk 2 orang anak 
sebesar Rp. 800.000,- (delapan ratus ribu rupiah) setiap bulan, maka Majelis Hakim akan memper-timban gkan nafkah yang layak untuk diberikan kepada dua orang anak Penggugat Rekonvensi dan Tergugat Rekonvensi yang tentunya disesuaikan dengan kemampuan Tergugat Rekonpvensi.

c. Perkara Nomor 03/Pdt.G/2018/PA SWL

Kasus yang sama dengan perkara Cerai Talak yang diajukan tanggal 02 Januari 2018, yang telah berjalan rukun dan damai selama 23 tahun lamanya, kemudian di tahun 2017 terjadi perselisihan dikarenakan tidak memiliki rasa kasih sayang dan membiarkan pemohon tinggal sendirian selama 3 bulan, dan telah dikarunia 2 oarang anak.

1) Anak Pertama, perempuan, lahir tanggal 25 September 1995

2) Anak Kedua, laki-laki, lahir tahun 2005.

Gugatan rekonvensi dari perkara ini bahwa Tergugat Rekonvensi bekerja sebagai buruh harian lepas, Penggugat Rekonvensi tidak tahu penghasilan Terguggat Rekonvensi kemudian Penggugat Rekonvensi mengajukan tuntutan kepada Tergugat Rekonvensi untuk memberikan biaya nafkah kepada 2 orang anak Rp. 2.000.000,- (dua juta rupiah) setiap bulannya.

Berdasarkan pertimbangan Majelis Hakim, Majelis menetapkan besaran biaya nafkah kepada 2 orang anak sesuai kesanggupan Tergugat Rekonvensi dan Tergugat Rekonvensi menyanggupinya untuk 2 orang anak sebesar Rp. 1.000.000,- (satu juta rupiah) setiap bulan, maka Majelis akan mempertimbangkan nafkah yang layak untuk diberikan kepada dua orang anak Penggugat Rekonvensi dan Tergugat Rekonvensi yang tentunya disesuaikan dengan kemampuan Tergugat Rekonvensi;

d. Perkara Nomor 151/Pdt.G/2018/PA SWL

Kasus yang sama dengan perkara Cerai Talak yang diajukan tanggal 9 Juli 2018, yang telah berjalan rukun dan damai selama 9 tahun 2 bulan lamanya, kemudian di tahun 2017 terjadi perselisihan dikarenakan tidak menghormati dan menghargai pemohon serta tidak sejalan lagi dalam membangun rumah tangga dan telah dikarunia 1 orang Anak, laki-laki,yang lahir pada tanggal 17 Maret 2014.

Berdasarkan pertimbangan Majelis Hakim terdapat dalam Amar Putusan untuk satu orang anak ditetpakan Rp 400.000,-(empat ratus ribu rupiah) setiap bulannya sampai anak tersebut dewasa.

Sementara Penggugat Rekonvensi menuntut biaya nafkah anak sebesar Rp.600.000,- (enam ratus ribu rupiah) perbulan, namun Terguggat Rekonvensi hanya menyanggupi untuk nafkah anak Rp. 400.000,(empat ratus ribu rupiah) setiap bulan hingga anak itu dewasa. Sehingga hakim tidak menetapkan untuk menambahkan nafkah anak $10 \%$ sampai $20 \%$ per tahun karena kesanggupan tergugat Rekonvensi hanya Rp. 400.000,- (empat ratus ribu rupiah) dari total penghasilanya. 
Dari keempat putusan perkara cerai talak di atas, Majelis Hakim tidak menerapkan Sema Nomor 3 tahun 2015 untuk menetapkan penambahan nafkah anak pasca perceraian. Nafkah anak dibayarkan atas kesanggupan ayah nya dan berdasarkan wawancara dengan Hakim Pengadilan Agama Sawahlunto "apabila hakim tidak menambahkan nafkah anak 10\% sampai $20 \%$ seperti yang ditetapkan Sema Nomor 3 tahun 2015 didalam amar putusanya ini tidak memiliki konsekuensi apa-apa sesuai sifat Sema Nomor 3 Tahun 2015 hanya bersifat himbaun bukan suatu keharusan untuk diterapkan karena sejatinya nafkah itu disesuaikan kemampuan si pemberi nafkah. Sehingga tidak adanya pelanggaran kewajiban hakim untuk mematuhi dalam penerapan SEMA No 3 tahun 2015 akan tetapi mematuhinya hanya sebagai pedoman bagi hakim dalam menerapkan hukum, hakim juga memiliki argumen dalam memutuskan suatu perkara dari kesepakatan antara penggugat dan tergugat dalam proses jawab menjawab dan ayah yang mengalami kesusahan dalam menafkahi anaknya karena faktor ekonomi sehingga hakim tidak menerapkan Sema Nomor 3 tahun 2015. (Dermawan, 2020)

$\begin{array}{llr}\text { ANALISIS } & \text { HUKUM } & \text { ISLAM } \\ \text { TERHADAP } & \text { SURAT } & \text { EDARAN } \\ \text { MAHKAMAH } & \text { AGUNG } & \text { NOMOR 3 } \\ \text { TAHUN } & 2015 & \text { TENTANG } \\ \text { PENAMBAHAN NAFKAH } & \text { ANAK }\end{array}$

Di antara kewajiban orang tua terhadap anaknya adalah memberi nafkah, seorang ayah berkewajiban untuk memberikan jaminan nafkah terhadap anaknya, baik pakaian, tempat tinggal. Nafkah berasal dari kata الانفاقyang berarti mengeluarkan (Bahri, 2015), nafkah merupakan semua kebutuhan dan keperluan yang berlaku menurut keadaan dan tempat serta bergantung pada kemampuan orang yang berkewajiban menurut kebiasaan suatu tempat. (M. Ali \& Khairuna, 2017) Dalam putusan Pengadilan Agama Sawahlunto yang sudah Peneliti dapatkan, Pengadilan Agama Sawahlunto memutuskan mengenai biaya nafkah anak dibebankan kepada ayah. Hal ini sesuai dengan Pasal 105 Huruf (a) dan (c) KHI, yang menyatakan bahwa Pemeliharaan anak yang belum mumayyiz atau belum berumur 12 tahun adalah hak ibunya dan dalam hal terjadinya perceraian biaya pemeliharaan ditanggung oleh bapaknya. Hal tersebut juga sudah dipertegas dalam UU Perkawinan Pasal 45 ayat (1), yang mewajibkan seorang ayah tetap memberi nafkah walaupun sudah terjadi perceraian.

Perubahan sosial pasca perceraian memberikan pengaruh pada masyarakat atas persepsi tentang peran serta figure seorang ayah dalam setiap tumbuh kembang anak. (Hidayati et al., 2015) Pada dasarnya ayah bertanggung jawab atas pemeliharaan anak-anaknya, baik orang tua keadaan rukun maupun dalam 
keadaan sudah bercerai. Dalam hal ini bisa dilihat bahwa anak-anak yang sering menjadi korban dalam perceraian, masih belum cukup umur, maka hadhanah merupakan solusinya dalam masalah ini. Hadhanah adalah memelihara seorang anak yang belum bisa hidup mandiri, yang meliputi biaya pendidikan atau pun biaya dalam kehidupan sehari-hari. Hal ini dirumuskan garis hukumnya dalam pasal 41 UU Perkawinan.

Pasal 41

1. "Baik ibu atau bapak tetap berkewajiban memelihara dan mendidik anakanaknya, semata-mata berdasarkan kepentingan anak, bilamana ada perselisihan mengenai pengasuhan anak-anak Pengadilan memberi keputusannya.

2. Bapak yang bertanggung jawab atas semua biaya pemeliharaan dan pendidikan yang diperlukan, bilamana bapak dalam kenyataan tidak dapat memenuhi kewajiban tersebut. Pengadilan dapat menentukan bahwa ibu ikut memikul biaya tersebut.

3. Pengadilan dapat mewajibkan kepada bekas suami untuk memberikan biaya penghidupan dan atau menentukan sesuatu kewajiban bagi bekas istri".

Mengenai tanggung jawab orang tua juga disebutkan dalam pasal $9 \mathrm{UU}$ Kesejahteraan Anak yang menyatakan bahwa "orang tua adalah yang pertamatama bertanggung jawab atas terwujudnya kesejahteraan anak secara rohani, jasmani maupun sosial".

Dalam konsep hukum Islam tanggung jawab biaya pemeliharaan anak berada di pundak ayah sebagai kepala rumah tangga. Meskipun dalam hal ini tidak menutup kemungkinan bahwa istri dapat membantu suami dalam menanggung kewajiban ekonomi tersebut. Karena itu yang terpenting adalah adanya kerja sama dan tolong menolong antara suami dengan istri dalam memelihara anak dan menghantarkannya hingga dewasa. Dalam Al-Quran mengisyaratkan agar ibu tidak menderita karena si anak, demikian juga seorang ayah tidak menderita karena anak. Ini dimaksudkan agar orang tua memenuhi kewajiban menurut kemampuannya. Apabila kedua orang tuanya berhalangan, tanggung jawab tersebut dapat dialihkan kepada keluarganya yang mampu. Sebagai mana firman Allah SWT QS al-Baqarah: 233 yang berbunyi:

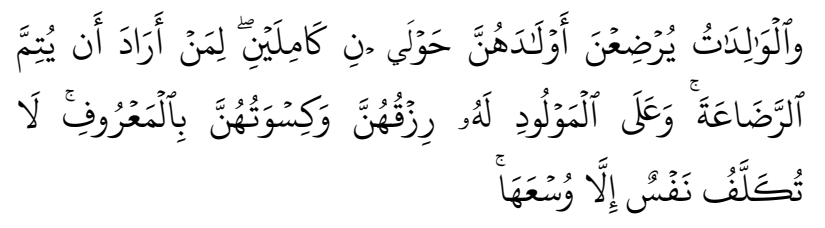

"Para ibu hendaklah menyusukan anakanaknya selama dua tahun penuh, Yaitu bagi yang ingin menyempurnakan penyusuan. dan kewajiban ayah memberi Makan dan pakaian kepada Para ibu dengan cara ma'ruf. seseorang tidak dibebani melainkan menurut kadar kesanggupannya. Janganlah seorang ibu menderita kesengsaraan karena anaknya dan seorang ayah karena anaknya". (QS. AlBaqarah [2]: 233)

Berdasarkan ayat di atas terdapat kewajiban ayah memberikan nafkah yang berupa sandang, pangan dan papan dengan kemampuan ayah. Kemudian dalam perspektif hukum Islam, urutanurutan yang mesti dipelihara dalam menjaga kepentingan al-daruriyah, alhajiyah, dan tashniyah, maka penulis cenderung menggunakan urutan yang dikemukakan oleh ulama pada umunya, yaitu memelihara agama (hifzh al-din), memelihara jiwa (hifzh al-nafs), memelihara akal (hifzh al-'aql), memelihara 
keturunan (hifzh al-nasl) dan memelihara harta (hifzh al-mal). Dari kelima pembagian maqasid syariah yang sangat relevan dengan penelitian ini adalah memelihara keturunan, karena hadirnya SEMA No 3 tahun 2015 tentang penambahan nafkah anak $10 \%$ sampai $20 \%$ pertahun merupakan wujud nyata atas kemaslahatan dalam menjaga keturunan.

Dalam nanalisis penulis, perihal hak nafkah anak pasca perceraian di wilayah hukum Pengadilan Agama Sawahlunto yang tidak sesuai dengan hadirnya Sema Nomor 3 tahun 2015 (hakim yang tidak menerapkan SEMA) tidak sejalan dengan maqasid syariah dikarenakan akan merusaknya eksitensi keberadaan hubungan keturunan dan kekurangan kebutuhan anak yang ditinggalkan, Majelis Hakim yang tidak menerapkannya memiliki argument bahwa nafkah itu ditetapkan berdasarkan atas kemampuan ayah. Sedangkan yang menerapkan Sema Nomor 3 tahun 2015 agar terpenuhi kebutuhan anak sesuai perkembangan ekonomi tiap tahun dan akan menjaga eksistensi keberadaan hubungan keturunan, sehingga perlu adanya Sema Nomor 3 tahun 2015 agar tercapai kemaslahatan suatu hukum, hal ini sesuai dengan konsep kemaslahatan salah satunya menjaga keberadaan keturunan. Kemudian dengan hadirnya Sema Nomor 3 tahun 2015 dapat terpenuhinya kebutuhan bagi anak atas penambahan nafkah $10 \%$ sampai $20 \%$ per tahun. (Dermawan, 2020)

Dalam putusan Pengadilan Agama Sawahlunto yang tidak menerapkan Sema Nomor 3 tahun 2015 sangat erat kaitannya dengan prespektif Maqasid Syariah bagian keturunan maka akan tidak terpenuhi nafkah anak yang ditinggalkan sebab kebutuhan ekonomi dari tahun ke tahun terus meningkat. Dengan tidak menerapkan Sema Nomor 3 tahun 2015, maka tidak tercapainya kemaslahatan anak yang ditinggalkan, bahkan anak akan dirugikan atau diabaikan dan dampak terburuknya adalah akan merusak keturunan. Dengan demikian, perlu adanya antisipasi bagi hakim agar tercukupinya kebutuhan anak dan terjaganya keturunan. (Zulfa, 2020)

\section{PENUTUP}

Dari hasil penelitian yang Peneliti lakukan dapat disimpulkan sebagai berikut:

1. Secara Filosofis lahirnya Sema Nomor 3 tahun 2015 sebagai harmonisasi antara hukum Islam dengan hukum positif di Indonesia, dimana Indonesia filsafat hukum yang dianut adalah filsafat positifis yang menyatakan bahwa hukum adalah perintah dari penguasa yang berdaulat sehingga dengan diadobkannya hukum Islam yang kemudian diundangkan ke dalam norma tertulis akan memberikan jaminan kepastian hukum. Kepastian hukum tersebut merupakan cita atau ide dasar yang digagas oleh filsafat positivis, dengan demikian lahirnya Sema Nomor 3 tahun 2015 adalah jaminan kepastian hukum bagi hakim untuk dapat menambahkan nafkah anak yang diakibatkan percerain kedua orang tuanya. Hal ini perlu dilakukan agar secara yuridis formal setiap orang tua yang bercerai tetap berkewajiban 
untuk memberikan nafkah kepada anak-anaknya khusunya bagi ayah.

2. Bahwa dari hasil penelitian di Pengadilan Agama Sawahlunto, tentang penerapan Sema Nomor 3 tahun 2015 penambahan nafkah anak $10 \%$ sampai $20 \%$ per tahun, bagi hakim yang menerapkan Sema Nomor 3 tahun 2015 setiap tahunya agar anak yang ditinggalkan tidak kekurangan dalam memenuhi kebutuhan setiap harinya dan hal ini sesuai kemampuan ayah sehingga akan tercukupi dan terpenuhi nya hak-hak anak sampai mereka mandiri, sementara dalam putusan yang tidak menerapkan Sema Nomor 3 tahun 2015 mejelis hakim mempertimbangkan bahwa bapak tidak memiliki kemampuan untuk menambah nafkah anak $10 \%$ sampai $20 \%$ per tahun, sehingga hakim tidak menerapkan Sema Nomor 3 Tahun 2015 dalam putusan, kemudian sifat Sema Nomor 3 tahun 2015 hanya sebatas himbauan (fakultatif) dan bukan keharusan (impetatif) sehingga tidak ada kewajiban bai hakim untuk berpedoman pada Sema dimaksud.

3. Dari perspektif hukum Islam, Maqasid Syariah dan relevansinya dengan Sema Nomor 3 Tahun 2015 tentang penambahan nafkah anak $10 \%$ sampai $20 \%$ per tahun, yang akan menciptakan hukum yang memberikan kemaslahatan. Sema ini akan memberikan kemaslahatan dalam bentuk menjaga keturunan, serta terpenuhi kebutuhan anak yang ditinggalkan atas penambahan nafkah per tahun dikarena iflansi keuangan tiap tahun terus meningkat. Sehingga butuh antisipasi agar terjaganya kebutuhan anak dengan adanya Sema Nomor 3 tahun 2015.

\section{DAFTAR PUSTAKA}

Ali, A. (2002). Menguak Tabir Hukum, Suatu Kajian Filosofis dan Sosiologis, Cet II. Penerbit Gunung Agung.

Ali, Z. (2006). Hukum Perdata Islam Di Indonesia Jakarta: Sinar Grafika, Cet ke1.

Asnawi, M. N. (2016). Implementasi Jurimetri Dalam Penentuan Jumlah Nafkah Anak / Jurimetrics In Deciding Child Support Allowances. Jurnal Hukum Dan Peradilan, 5(3)

Bahri, S. (2015). Konsep Nafkah dalam Hukum Islam. Kanun Jurnal Ilmu Hukum, 17(2)

Busyro. (2015). Fiqih Maqasid. Adelina Bersaudara.

Daud, M. (2004). Bunga Rampai Hukum Pidana dan Kriminologi. Pustaka Bangsa.

Efendi, R. (2016). Kedudukan Masa Tunggu Eksekusi Bagi Terpidana Mati Dalam Sistem Pemidanaan. Universitas Andalas Padang.

Elimartati. (2016). Harta kekayaan dalam Perkawinan. Dialetktika.

Erwin, M. (2011). Filsafat Hukum Refleksi Kritis Terhadap Hukum. PT Raja Grafindo Persada.

Hidayati, F., Kaloeti, D. V. S., \& Karyono. (2015). Peran Ayah Dalam Pengasuhan Anak. Insight: Jurnal Ilmiah Psikologi, 17(2),

Instruksi Presiden Nomor 1 Tahun 1991 tentang Kompilasi Hukum Islam.

Is, M. S., \& Sobandi. (2019). Hukum Ketenaga Kerjaan di Indonesia. Kencana.

Jaya, A. (1996). Konsep Maqasid Syariah. PT 
Raja Grafindo Persada.

M. Ali, R., \& Khairuna, Z. F. (2017). Hak Nafkah Anak Pegawai Negeri Sipil Setelah Perceraian (Studi Kasus Mahkamah Syarâ€ $€^{\mathrm{TM}}$ iyah Banda Aceh). SAMARAH: Jurnal Hukum Keluarga Dan Hukum Islam, 1(2)

Rahman, A. (1996). Perkawinan dalam Syariat Islam. PT Rineka Cipta.

Rozali, I. (2017). Konsep Memberi Nafkah bagi Keluarga dalam Islam. Jurnal Intelektualita: Keislaman, Sosial Dan Sains, 6(2)

Rusyd, I. (1990). Bidayah Al-Mujtahid, Penerjemah; M.A. Abdurrahman. AsySyifa.

Sabiq, S. (2009). Fiqh Sunnah 4, Terjemah: Abdur Rahim dan Masruhin. Cakrawala Publising.

Sabiq, S. (2011). Fiqh Sunnah 3, Terjemah: Abdur Rahim dan Masruhin. Cakrawala Publising.

Safala, U. (2015). Nafkah Anak Pasca
Perceraian Menurut Abu Zahrah dan Implikasinya Bagi Pelaksanaan hukum Islam di Indonesia. Justitia Islamica, 12(267-304).

Sarianti, B. (2019). Tingkat Kepatuhan Ayah Membayar Nafkah Anak Pasca Perceraian. Supremasi Hukum: Jurnal Penelitian Hukum, 27(2

Shindiq, S. (2011). Ushul Fiqih, Cet Ke 1. Kecana.

Soekanto, S., \& Sri Mamudji. (n.d.). Penelitian Hukum Normatif. Rajawali Press.

Syahrani, T. (2009). Figh Munakahat. Rajawali Press.

\section{Wawancara:}

Doni Dermawan, Ketua PA Sawahlunto, wawancara, 18 Mei 2020

Emmy Zulfa, Panitera PA Sawahlunto, wawancara, 16 Mei 2020 